Review

\title{
Probiotics and their potential applications in active edible films and coatings
}

\author{
Paula J.P. Espitia ${ }^{\text {a,* }}$, Rejane A. Batista ${ }^{\text {b }}$, Henriette M.C. Azeredo ${ }^{c}$, Caio G. Otoni ${ }^{\text {d,e }}$ \\ ${ }^{a}$ Nutrition and Dietetics School. University of Atlántico - Universidad del Atlántico - Puerto Colombia, Atlántico, Colombia \\ ${ }^{\mathrm{b}}$ Northeast Biotechnology Network (PGP - RENORBIO), Federal University of Sergipe - São Cristovão, SE 49100-000, Brazil

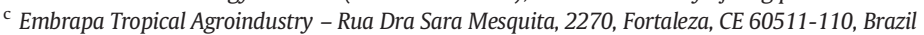 \\ d PPG-CEM, Department of Materials Engineering, Federal University of São Carlos - Rod. Washington Luís, km 235, São Carlos, SP 13565-905, Brazil \\ e National Nanotechnology Laboratory for Agribusiness, Embrapa Instrumentation - Rua XV de Novembro, 1452, São Carlos, SP 13560-979, Brazil
}

\section{A R T I C L E I N F O}

\section{Article history:}

Received 15 June 2016

Received in revised form 13 October 2016

Accepted 16 October 2016

Available online 17 October 2016

\section{Keywords:}

Probiotic

Food packaging

Active packaging

Antimicrobial activity

Biopolymer

Food preservation

\begin{abstract}
A B S T R A C T
The global market for probiotics has been increasingly growing in recent years guided by the rising consumers' demand for healthy diets and wellness. This has caused food industries to develop new probiotic-containing food products as well as researchers to study specific characteristics of probiotics as well as their effects on human health. Probiotics are defined as live microorganisms that confer a health benefit to the host when administered in adequate quantities. Probiotics have been added to several food products as well as incorporated into biopolymeric matrices to develop active food packaging as an alternative method for controlling foodborne microorganisms, improving food safety, and providing health benefits. This review includes definition of probiotics, description of their effects on human health, discussion on their applications in edible biopolymeric matrices to develop active edible films and coatings, as well as the probiotics-related legislation.
\end{abstract}

(c) 2016 Elsevier Ltd. All rights reserved.

\section{Contents}

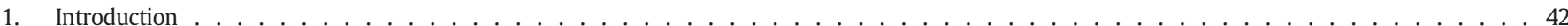

2. Probiotics: history, definition, and effect on human health. . . . . . . . . . . . . . . . . . . . . . . . . . . . 43

3. Probiotics in active/bioactive edible films and coatings . . . . . . . . . . . . . . . . . . . . . . . . . . . . . . . . 45

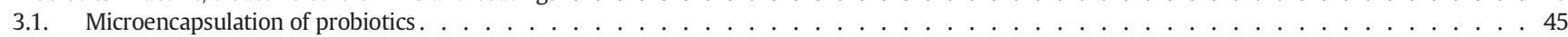

3.2. Probiotic edible films and coatings . . . . . . . . . . . . . . . . . . . . . . . . . . . . . . 46

3.2.1. Studies focused on probiotic viability in films . . . . . . . . . . . . . . . . . . . . . . . . . . . . . . . 46

3.2.2. Studies focused on inhibitory activity against other microbial species . . . . . . . . . . . . . . . . . . . . . . . . 48

3.3. Food matrix consideration and potential for probiotic films and coatings applications . . . . . . . . . . . . . . . . . . . . . . 49

4. Regulations related to probiotics and active food packaging . . . . . . . . . . . . . . . . . . . . . . 49

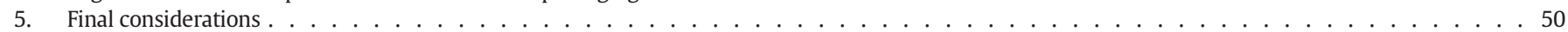

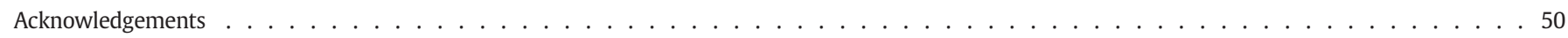

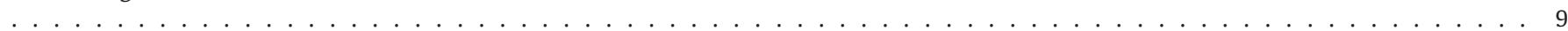

Abbreviations: CFU, colony-forming units; CMC, carboxymethyl cellulose; COS, chitosan oligosaccharide; EFSA, European Food Safety Authority; EU, European Union; FAO, Food and

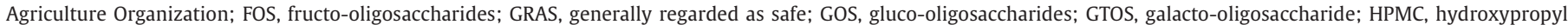
methylcellulose; MC, methylcellulose; TSA, tryptose soy agar; WHO, World Health Organization; WPC, whey protein concentrate.

* Corresponding author.

E-mail addresses: perez.espitia@gmail.com (P.J.P. Espitia), rejaneabatista@gmail.com (R.A. Batista), henriette.azeredo@embrapa.br (H.M.C. Azeredo), cgotoni@gmail.com (C.G. Otoni). 


\section{Introduction}

Consuming foods with probiotics has increased because of consumer concerns regarding healthy diets and wellness. The global market for probiotics - including their use as ingredients, supplements, and incorporation in food products - accounted for 14.9 and 16.0 billion US dollars in 2007 and 2008, respectively (Granato, Branco, Nazzaro, Cruz, \& Faria, 2010). In 2010 and 2011, the global sales of probiotics increased to 21.6 and 24.23 billion dollars, respectively. According to the Transparency Market Research, disclosed in 2015, the global market for probiotics was valued at 62.6 billion dollars in 2014, and is estimated to reach 96.0 billion dollars by 2020 . This has aroused the attention of food industries to produce new food products containing probiotics as well as researchers who have studied specific characteristics of probiotics and their effects on human health.

The term probiotic is a relatively new word. It means "for life" and describes bacteria with beneficial effects on humans and animals (FAO, 2001). Indeed, probiotics were originally defined as a "mono- or mixed culture of live micro-organisms which, when applied to man or animal, affects beneficially the host by improving the properties of indigenous microflora" (Huis Veld \& Havenaar, 1991). Probiotics are defined by $\mathrm{FAO} / \mathrm{WHO}$ as "live microorganisms which, when administered in adequate amounts, confer a health benefit to the host" (FAO, 2002). The Japanese definition of probiotics includes cells of nonviable microorganisms that provide health benefits in addition to live microorganisms (Salminen, Ouwehand, Benno, \& Lee, 1999). The concept of viability should be used with care as it is defined by most regulatory authorities as culturability, which in turn is highly depended upon culture conditions and media.

Reviews have shown positive effects of probiotics at in vivo studies, as well as on human health (Aureli et al., 2011; Clarke, Cryan, Dinan, \& Quigley, 2012; Hempel et al., 2012; Mattila-Sandholm et al., 1999; Ooi \& Liong, 2010; Singh, Kallali, Kumar, \& Thaker, 2011; Satish Kumar \& Arul, 2015). Probiotics have been incorporated into several food products and supplements, most of them dairy products, such as cheeses, dairy desserts, ice-cream, although fermented milks such as yogurts are the most popular matrices, which can be obtained from bovine (Batista et al., 2015), caprine (Ranadheera, Evans, Adams \& Baines, 2012a, b; Ranadheera, Evans, Adams \& Baines, 2016a, b) and ovine (Balthazar et al., 2016) milk. Recent studies regarding probiotic microorganisms and their applications in food matrices are presented in Table 1.

The most frequently commercially used bacteria belong to the genera Lactobacillus and Bifidobacterium, although Streptococcus thermophilus and Saccharomyces boulardii are available in some dairy products (Rastall, Fuller, Gaskins, \& Gibson, 2000). Moreover, nondairy probiotic products have drawn attention due to the growing interest in veganism, as well as to the higher number of consumers with diet restrictions such as lactose intolerance, allergies to milk proteins, and even cholesterol restriction. Hence, non-dairy products (e.g. fruit juices, minimally processed fruits, and fermented vegetables) allow the development of probiotic foods free of cholesterol, lactose and allergens usually found in dairy products (Martins et al., 2013).

Alternatively, probiotics may be carried within edible polymer matrices used in the food packaging industry. In this way, probiotics - as well as many other active compounds (Otoni, Espitia, Avena-Bustillos, \& McHugh, 2016) - have been incorporated into biopolymeric matrices to develop active/bioactive food packaging materials as an alternative method for controlling pathogenic microorganisms and improving food safety, besides having the potential to favor consumer health. An overview of the chronological scenario concerning the investigations on probiotics and on food packaging demonstrates that the number of publications on these topics independently has been increasing remarkably throughout the past couple of decades (Fig. Fig. 1). However, to the best of our knowledge, literature on the applications of probiotics in active food packaging is scarce, and thus far there is no review article focused solely on this subject. This review highlights the nature of probiotics and their incorporation into biopolymer materials intended for active food packaging applications as well as legislation related to probiotics.

\section{Probiotics: history, definition, and effect on human health}

Ancient civilizations, such as the Greeks and Romans, used fermented dairy foods to maintain health. However, research on microorganisms in fermented food products and their effects on human health have only been studied recently. The history of probiotics started in 1908 when Élie Metchnikoff, Nobel Laureate at the Pasteur Institute, established the relationship between health and longevity with the ingestion of bacteria from yogurt. Dr. Metchnikoff proposed that the bacteria helped control infections caused by enteric pathogens and regulated toxaemia, both of which playing major roles in aging and mortality. This observation resulted in increased yogurt production and consumption (Shah, 2007).

The term probiotic has been widely used. According to HamiltonMiller, Gibson, and Bruck (2003), this term was first used by Lilly and Stillwell in 1965 and referred to observations of in vitro protozoa growth stimulated by other protozoa. During the following decade, the term probiotic was used by Fujii and Cook in 1973 and denoted synthetic chemicals in mice that conferred protection against Staphylococcus aureus infection. In 1974, the term was used by Parker in a wider sense to refer to microorganism interactions with the animal or human host, i.e. "organisms and substances, which contribute to intestinal microbial balance". Several works concerning probiotics have been published since then.

In 2002, FAO/WHO held an expert consultation to evaluate health and nutritional properties of probiotics and establish a definition for probiotics (FAO, 2001). Recently, Wassenaar and Klein (2008) slightly modified the definition to "food or food supplements containing defined microorganisms in sufficient numbers to reach the gut in viable status resulting in positive health effects after consumption". The authors claim this definition does not contradict the internationally and scientifically accepted definition, although they added qualitative (defined microorganisms) and quantitative (sufficient numbers) requirements to the presumed positive health effects.

Probiotic effects are strain specific, thus knowledge of the probiotic genus and species is necessary to obtain the desired effects in the host. The main characteristics of probiotic strains in their relationship with the host are resistance to gastric and bile acid, adherence to mucus or human epithelial cells, antimicrobial activity against pathogenic bacteria, and the ability to reduce pathogen adhesion to surfaces and bile salt hydrolase activity (FAO, 2002).

There are several mechanisms by which probiotics may benefit human, including production of antimicrobial substances, strengthening of intestinal barrier, modulation of immune response, and antagonism of pathogenic microorganisms either by production of antimicrobial agents or by competition for binding sites, nutrients, and growth factors (FAO, 2001; Marco, Pavan, \& Kleerebezem, 2006; Parvez, Malik, Ah Kang, \& Kim, 2006).

When probiotic microorganisms are incorporated into foods, they must be able to survive through the digestive tract and successfully proliferate in the gut. Thus, they must be resistant to gastric juices and be able to grow in the conditions of the intestine. An interesting option is to use a food matrix that protects them and favors their survival.

Several factors affect the survival of ingested probiotics in the gastrointestinal tract, including stomach acid, bile salt concentrations, time of exposure, and probiotic species and strains. However, many probiotics are able to pass through the gastrointestinal tract and enter the colon in viable numbers in order to impart beneficial effects. In this regard, recent studies have explored the effect of the food matrix in the survival of probiotic to the conditions of the gastrointestinal tract and their adhesion to intestinal cells. Ranadheera, Baines \& Adams (2010) have deeply 
Table 1

Recent studies regarding probiotic applications in food matrices.

\begin{tabular}{|c|c|c|c|}
\hline Probiotic microorganism & Food matrix & Research target & Reference \\
\hline $\begin{array}{l}\text { Streptococcus thermophiles } \\
\quad \text { salivarius spp. TA } 040 \\
\text { Lactobacillus delbrueki spp. } \\
\text { bulgaricus LB340 } \\
\text { Lactobacillus acidophilus } \\
\text { La14 } \\
\text { Bifidobacterium longum } \\
\text { BL05 }\end{array}$ & Yogurt & $\begin{array}{l}\text { Evaluation of quality parameters of strawberry probiotic yogurt added with glucose oxidase. To do so, } \\
\text { developed product was compared with commercial probiotic products. }\end{array}$ & $\begin{array}{l}\text { Batista et al., } \\
2015\end{array}$ \\
\hline $\begin{array}{l}\text { Streptococcus thermophilus } \\
\text { TA040 } \\
\text { Lactobacillus delbrueckii ssp. } \\
\text { bulgaricus LB340 } \\
\text { Bifidobacterium longum } \\
\text { BL05 } \\
\text { Lactobacillus acidophilus } \\
\text { LA14 }\end{array}$ & & Incorporation of glucose oxidase in increasing levels and its effect in the developed final product. & $\begin{array}{l}\text { Cruz et al., } \\
2012\end{array}$ \\
\hline $\begin{array}{l}\text { Lactobacillus acidophilus } \\
\quad \text { LA5 } \\
\text { Bifidobacterium animalis } \\
\text { subsp. lactis BB12 } \\
\text { Propionibacterium jensenii } \\
702\end{array}$ & & $\begin{array}{l}\text { Assessment of the viability of tested probiotic microorganisms in plain and stirred fruit yogurts based } \\
\text { on goats' milk, as well as product characteristics (physicochemical and sensorial). }\end{array}$ & $\begin{array}{l}\text { Ranadheera } \\
\text { et al., 2012a }\end{array}$ \\
\hline $\begin{array}{l}\text { Streptococcus thermophiles } \\
\text { Lactobacillus delbrueckii ssp. } \\
\text { bulgaricus }\end{array}$ & & $\begin{array}{l}\text { Evaluation of the physicochemical parameters of sheep yogurt containing inulin at different } \\
\text { concentrations. }\end{array}$ & $\begin{array}{l}\text { Balthazar et } \\
\text { al., } 2016\end{array}$ \\
\hline $\begin{array}{l}\text { Lactobacillus acidophilus } \\
\text { LA14 } \\
\text { Bifidobacterium longum } \\
\text { BL05 }\end{array}$ & $\begin{array}{l}\text { Yogurt and whey } \\
\text { beverage }\end{array}$ & $\begin{array}{l}\text { Evaluation of the efficiency of two different probiotic matrices on the immune system in Wistar rats } \\
\text { exercised to the point of exhaustion after receiving the developed products for } 14 \mathrm{~d} \text {. }\end{array}$ & $\begin{array}{l}\text { Lollo et al., } \\
2013\end{array}$ \\
\hline $\begin{array}{l}\text { Streptococcus salivarius } \\
\text { thermophilus ssp. TA040 } \\
\text { Lactobacillus acidophilus } \\
\text { NFCM }\end{array}$ & Fermented milk & $\begin{array}{l}\text { Evaluation of the efficiency of the developed product submitted to ultra-high temperature and } \\
\text { dynamic high pressure in maintaining the immune system of rats exercised to exhaustion after } \\
\text { receiving the product for } 14 \mathrm{~d} \text {. }\end{array}$ & $\begin{array}{l}\text { Lollo et al., } \\
2015-2\end{array}$ \\
\hline $\begin{array}{l}\text { Streptococcus thermophilus } \\
\text { TA40 } \\
\text { Lactobacillus acidophilus } \\
\text { NFCM } ®\end{array}$ & & Determination of the influence of dynamic high pressure on the probiotic developed product. & $\begin{array}{l}\text { Oliveira et al., } \\
2014\end{array}$ \\
\hline $\begin{array}{l}\text { Lactobacillus acidophilus } \\
\quad \text { LA5 } \\
\text { Bifidobacterium animalis } \\
\text { subsp. lactis BB12 } \\
\text { Propionibacterium jensenii } \\
702\end{array}$ & $\begin{array}{l}\text { Fermented dairy drink } \\
\text { made from goats' milk }\end{array}$ & $\begin{array}{l}\text { Development of a fermented dairy drink based on goats' milk and incorporated with Lactobacillus } \\
\text { acidophilus LA5, Bifidobacterium animalis subsp. lactis BB12 and Propionibacterium jensenii 702, alone } \\
\text { or in combination; and determination of main developed product characteristics (microbial, } \\
\text { physicochemical, and sensorial). }\end{array}$ & $\begin{array}{l}\text { Ranadheera } \\
\text { et al., 2016a }\end{array}$ \\
\hline Lactobacillus casei Zhang & Minas fresh cheese & $\begin{array}{l}\text { Evaluation of the L. casei Zhang incorporation on main characteristics (physicochemical, optical, } \\
\text { rheological and sensorial) of the developed product. }\end{array}$ & $\begin{array}{l}\text { Dantas et al., } \\
2016\end{array}$ \\
\hline $\begin{array}{l}\text { Lactobacillus acidophilus } \\
\text { LA5 }\end{array}$ & & $\begin{array}{l}\text { Determination of the sodium reduction and arginine incorporation effect on quality parameters of the } \\
\text { developed product. }\end{array}$ & $\begin{array}{l}\text { Felicio et al., } \\
2016\end{array}$ \\
\hline $\begin{array}{l}\text { Lactobacillus acidophilus } \\
\text { LA-5 }\end{array}$ & & $\begin{array}{l}\text { Assessment of increasing concentration of probiotic microorganisms on physicochemical parameters } \\
\text { and sensory acceptance of developed product. }\end{array}$ & $\begin{array}{l}\text { Gomes et al., } \\
2011\end{array}$ \\
\hline $\begin{array}{l}\text { Lactobacillus acidophilus } \\
\text { LA14 } \\
\text { Bifidobacterium longum } \\
\text { BL05 }\end{array}$ & & $\begin{array}{l}\text { Evaluation of key parameters of the immune system of Wistar rats that were submitted to acute, } \\
\text { intense physical exercise after receiving a diet with the developed product for } 14 \mathrm{~d} \text {. }\end{array}$ & $\begin{array}{l}\text { Lollo et al., } \\
2012\end{array}$ \\
\hline $\begin{array}{l}\text { Lactobacillus acidophilus } \\
\text { LA14 } \\
\text { Bifidobacterium longum } \\
\text { BL05 }\end{array}$ & & $\begin{array}{l}\text { Assessment of the effect of developed product consumption on arterial hypertension parameters } \\
\text { while tested in spontaneous hypertensive rats (SHRs, } 7 \text { weeks old). }\end{array}$ & $\begin{array}{l}\text { Lollo et al., } \\
2015\end{array}$ \\
\hline $\begin{array}{l}\text { Lactobacillus acidophilus } \\
\text { LA14 } \\
\text { Bifidobacterium lactis BL04 }\end{array}$ & Petit Suisse cheese & $\begin{array}{l}\text { Assessment of the ideal sucrose concentration and other sweeteners (stevia, sucralose, aspartame, } \\
\text { and Neotame on the viability of the starter and probiotic cultures while incorporated in the developed } \\
\text { product. }\end{array}$ & $\begin{array}{l}\text { Esmerino et } \\
\text { al., } 2013\end{array}$ \\
\hline $\begin{array}{l}\text { Lactobacillus acidophilus } \\
\text { Bifidobacterium lactis }\end{array}$ & & $\begin{array}{l}\text { Estimation of the optimum sucrose concentration and predictions of optimum sucrose level based on } \\
\text { acceptance testing of the developed product. }\end{array}$ & $\begin{array}{l}\text { Esmerino et } \\
\text { al., } 2015\end{array}$ \\
\hline $\begin{array}{l}\text { Lactobacillus acidophilus } \\
\text { LAC4 }\end{array}$ & & $\begin{array}{l}\text { Evaluation of the effect of antioxidants compounds on the physicochemical, rheological and sensory } \\
\text { characteristics of developed product. }\end{array}$ & $\begin{array}{l}\text { Pereira et al., } \\
2016\end{array}$ \\
\hline $\begin{array}{l}\text { Bifidobacterium animalis } \\
\text { ssp. lactis DN173-010 }\end{array}$ & & & \\
\hline $\begin{array}{l}\text { Lactobacillus acidophilus } \\
\text { LAC4 } \\
\text { Bifidobacterium animalis } \\
\text { sub sp. lactis DN173-010 }\end{array}$ & & $\begin{array}{l}\text { Assessment of the performance of the jabuticaba skin extract in minimizing the oxidative stress in the } \\
\text { developed product. }\end{array}$ & $\begin{array}{l}\text { Pereira et al., } \\
2016-2\end{array}$ \\
\hline
\end{tabular}

reviewed the relationship among probiotic efficacy and food matrices (and their physicochemical properties), indicating that food matrix selection is a key factor that should be considered when developing functional probiotic food. In this context, Ranadheera et al. (2012a, b) have studied the effect of three different food matrices (goat's milk ice cream, plain and fruit yogurts) on probiotic viability of Lactobacillus 


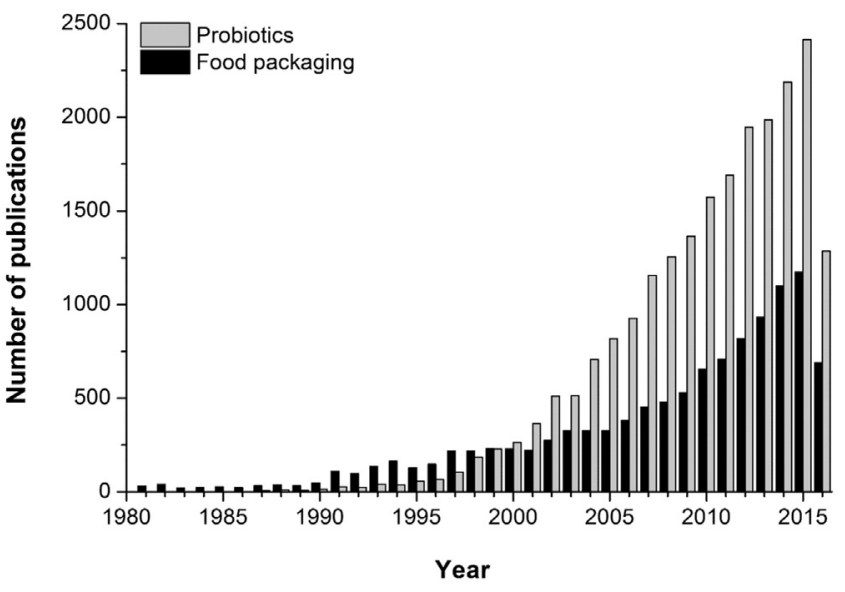

Fig. 1. Number of publications on probiotics (topic: probiotic*) and on food packaging (topic: food packag*) retrieved from Web of Science ${ }^{\mathrm{TM}}$ Core Collection.

acidophilus LA5, Bifidobacterium animalis subsp. lactis BB12 and Propionibacterium jensenii 702, finding that, among the tested food matrices, ice cream presented the best potential to ensure probiotic viability in simulated gastrointestinal conditions (acid and bile tolerance), while fruit yogurt matrix allowed the best cell adhesion of probiotics. Also, probiotic survival to food processing conditions has been studied. In this context, Majeed et al. (2016) studied the survival of Bacillus coagulans MTCC 5856 in different functional foods, such as banana muffins and waffles for up to 12 months, coffee at extreme conditions $\left(90^{\circ} \mathrm{C}\right.$ for $2 \mathrm{~min}$ and at $77^{\circ} \mathrm{C}$ for $4 \mathrm{~h}$ ), chocolate fudge frosting, hot fudge toppings, peanut butter, strawberry and vegetable oil at room temperature up to 12 months. As a result, B. coagulans MTCC 5856 showed potential to be used as probiotic when developing innovative functional food products due to its stability towards processing and storage condition of tested food.

Although there is no consensus among the international scientific community about effective probiotic doses to achieve health effects, researchers have suggested minimum doses between $10^{6}$ and $10^{9}$ CFU $\mathrm{d}^{-1}$ to ensure therapeutic effects (Espírito Santo, Perego, Converti, \& Oliveira, 2011).

Fermented dairy products are considered good carriers for probiotic microorganisms. Other food matrices, such as fruits and vegetables, are considered potential carriers for these microorganisms because of the increasing lactose intolerance and vegetarianism among consumers (Martins et al., 2013).

Besides presenting beneficial health effects, probiotic microorganisms have also been related to effects against other (undesirable) microorganisms when inoculated into foods. In this regard, Alegre, Viñas, Usall, Anguera, and Abadias (2011) tested the antimicrobial activity of a probiotic culture (Lactobacillus rhamnosus GG) against two pathogens - Salmonella and L. monocytogenes. Fresh-cut apple wedges were immersed in solutions containing the probiotic bacteria $\left(10^{8} \mathrm{CFU} \mathrm{mL}{ }^{-1}\right)$ and/or the pathogens $\left(10^{5} \mathrm{CFU} \mathrm{mL} \mathrm{L}^{-1}\right)$, placed in polypropylene trays and sealed with a polypropylene plastic film. Results showed that Salmonella was not affected by $L$. rhamnosus GG, but the population of $L$. monocytogenes was $1 \log$ cycle lower in the presence of the probiotic. The probiotic viability was maintained above recommended levels $\left(10^{6} \mathrm{CFU} \mathrm{g}{ }^{-1}\right)$ until 14 days of storage at $5{ }^{\circ} \mathrm{C}$. Moreover, Fernandes et al. (2013) developed a dairy dessert incorporated with Lactobacillus acidophilus LA-5 as a probiotic microorganism and tested its antimicrobial activity against $L$. innocua by means of three formulations (F1: inoculated with L. acidophilus LA-5; F2: inoculated with L. innocua; F3: inoculated with both L. innocua and L. acidophilus LA-5). Differently from the results observed by Alegre et al. (2011), the findings by that study showed that the count of the probiotic microorganism diminished while studying product shelf life in formulation F1. Also, no antimicrobial effect was observed against $L$. innocua. In this regard, population of L. innocua increased in formulations F2 and F3, indicating a mutual benefit and positive growth effect among the tested probiotic and the target pathogen microorganisms. Similarly, Jesus et al. (2016) studied the interaction of Listeria monocytogenes and probiotic microorganisms (Lactobacillus acidophilus and Bifidobacterium lactis). They reported that $L$. monocytogenes can growth in probiotic cottage cheese in both condition, when product is submitted to adequate storage conditions $\left(4^{\circ} \mathrm{C} / 28\right.$ days), as well as in situations of temperature abuse (30\% of the shelf life at $4{ }^{\circ} \mathrm{C}$ and the remaining $70 \%$ at $12{ }^{\circ} \mathrm{C}$ ). Therefore, microbiological quality of food products incorporated with probiotic microorganisms should not rely on the protective effect of probiotic cultures but on the use of proper hygienic processing conditions and on the excellent microbiological quality of raw materials used.

\section{Probiotics in active/bioactive edible films and coatings}

For probiotics to play the intended role in human health, it is essential that both viability and the metabolic activity are maintained throughout food processing and supply chain, as well as within human gastrointestinal tract. Several methods have been tested to increase the quality of probiotic cultures, including exposure to sub-lethal heat or cold stress, osmotic stress, low $\mathrm{pH}$, and reduced redox potential (e.g. through the use of oxygen scavengers, oxygen-consuming microorganisms, and modified atmosphere packaging) (Nguyen et al., 2016); however, microencapsulation is by far the most exploited approach. When combined, microencapsulation and active edible packaging concepts denote a promising strategy for protecting and delivering probiotic species efficiently.

\subsection{Microencapsulation of probiotics}

Microencapsulation may be defined as the process of packing functional compounds (e.g. probiotic culture) into microcapsules made up of an encapsulant material (Vieira da Silva, Barreira \& Oliveira, 2016). When applied to probiotics, microencapsulation techniques are intended to carry and protect them from the detrimental action of $\mathrm{pH}$, oxygen, and light, to mention a few. Therefore, this process can diminish probiotic reactivity to the environment and prevent its degradation, besides masking unpleasant flavors and odors (Vieira da Silva et al., 2016). The encapsulation protocols are various, including spray drying (Li et al., 2016a, b; Ranadheera, Evans, Adams, \& Baines, 2015), highvoltage electrospinning/electrospraying (Coghetto et al., 2016; Gomez-Mascaraque, Morfin, Pérez-Masiá, Sanchez, \& Lopez-Rubio, 2016), extrusion, spinning disc, vortex bowl, micro nozzle array, impinging aerosol, coacervation, and emulsion (Krasaekoopt, 2013). Probiotic encapsulation methods have been extensively reviewed elsewhere (de Prisco \& Mauriello, 2016; Martín, Lara-Villoslada, Ruiz, \& Morales, 2015).

Microencapsulation has been combined to active packaging as an alternative means of incorporating probiotics. Probiotic microencapsulation stands out as a promising alternative for applying those microorganisms and replacing antibiotics, since this process allows the gradual release of compounds of interest in order to preserve the food (Favaro-Trindade, Pinho, \& Rocha, 2008; Mirzaei, Pourjafar, \& Homayouni, 2012). Thus, studies on the development of active food packaging featuring probiotic microorganism action are worthwhile despite the challenges involved in the encapsulation technique itself. Regarding the microencapsulation process, suitable encapsulating materials have been extensively studied, especially biodegradable polymers that can be also applied for active food packaging production. These include alginate (Etchepare et al., 2015; Sohail, Turner, Coombes, Bostrom, \& Bhandari, 2011), acetate (Fávaro-Trindade \& Grosso, 2002), chitosan (Krasaekoopt, Bhandari, \& Deeth, 2003), carboxymethyl cellulose (CMC), protein (Guérin, Vuillemard, \& Subirade, 2003; Vonasek, Le, \& Nitin, 2014), carrageenan, gelatin, and 
pectin (Burey, Bhandari, Howes, \& Gidley, 2009; Favaro-Trindade et al., 2008; Li et al., 2009). Altamirano-Fortoul, Moreno-Terrazas, QuezadaGallo, and Rosell (2012) used the combination of microencapsulation and starch-based coatings to incorporate Lactobacillus acidophilus. Those authors coated the surface of partially baked breads with a filmforming solution incorporated with $L$. acidophilus. According to Altamirano-Fortoul et al. (2012), L. acidophilus remained stable after the baking procedure, presenting counts of $10^{7} \mathrm{CFU} \cdot$ bread $^{-1}$. Thus, $L$. acidophilus can be used on bread surfaces by means of microcapsules incorporated in edible coatings, resulting in bread with additional health benefits provided by probiotics. L. rhamnosus GG has also been encapsulated in hydrogel beads comprising pectin, glucose, and calcium chloride ( $\mathrm{Li}$ et al., 2016a, b). Moreover, probiotics may also be encapsulated directly into food matrices. In this regard, a mixture of $L$. acidophilus LA5, Bifidobacterium animalis subsp. lactis BB12, and Propionibacterium jensenii 702 was microencapsulated into goats' milk (Ranadheera et al., 2015). As a result, the probiotics submitted to the encapsulation process maintained satisfactory viable levels $\left(10^{6}\right.$ $10^{8} \mathrm{cfu} / \mathrm{g}$ ); on the other hand, storage conditions at $30^{\circ} \mathrm{C}$ after processing reduced significantly their viability, while lactobacilli and propionibacteria were not affected when stored at $4{ }^{\circ} \mathrm{C}$.

\subsection{Probiotic edible films and coatings}

Increased consumer interest in health, nutrition, food safety, and environmental issues has led to improved research on the film-forming properties of biopolymers to produce edible films for food packaging (Espitia, Du, Avena-Bustillos, Soares, \& McHugh, 2013). Although edible films and coatings do not replace an external packaging - which is usually non-biodegradable and, for most probiotic bacteria, must act as a good barrier to oxygen (da Cruz, Faria, \& Van Dender, 2007) -, they help packaging in its food protecting function, since they reduce the rates of moisture and gas transfer between food and the surrounding environment, contributing to extend food stability. Edible films may thus reduce the required amount of packaging for each application, reducing the negative environmental impact caused by the discard of non-biodegradable materials. Apart from their passive protecting function, edible films and coatings may also play some active or bioactive roles.

The concepts of active and bioactive packaging have been sometimes used indiscriminately, but there are differences. Active food packaging systems are those which go beyond the traditional passive role of food protection and include desirable interactions with the food, in a way that is relevant to extend food stability; a typical active packaging is antimicrobial packaging, which interacts with the product or the headspace inside to decrease, prevent or delay microbial growth on food surfaces (Soares et al., 2009). In previous studies, biopolymers have been used to carry natural antimicrobial compounds such as essential oils (Botrel, Soares, Espitia, Sousa, \& Renhe, 2010; Espitia, Soares, Botti, \& Silva, 2011; Otoni, Avena-Bustillos, Olsen, Bilbao-Sáinz, \& McHugh, 2016; Tripathi \& Dubey, 2004), organic acids (Schirmer et al., 2009), enzymes (e.g. lysozyme) (Appendini \& Hotchkiss, 1997), and bacteriocins (Espitia, Otoni, \& Soares, 2016; Gálvez, Abriouel, López, \& Omar, 2007; Han, 2005). Active food packaging has been developed in response to consumer demand for safer and less processed food with extended shelf-life (Ahvenainen, 2003).

Bioactive food packaging systems, on the other hand, are those which may contribute to health benefits to the consumers (LopezRubio, Gavara, \& Lagaron, 2006). It is a novel approach of the concept of functional foods, which proposes that any food that may provide a health benefit beyond the traditional nutrients it contains may be considered as functional. Bioactive packaging materials would thus withhold bioactive agents, which are eventually released into the food product (Lopez-Rubio et al., 2006). In the specific case of edible bioactive films and coatings, this release is not even required, since the film/coating itself is supposed to be eaten with the food. Bioactive packaging has been reviewed elsewhere (Lopez-Rubio et al., 2006).

The incorporation of probiotic cultures into edible coatings was first proposed in 2007 by Tapia et al. (2007). Thus, research on the development of films and coatings incorporated with probiotics intended as active food packaging is still emerging, with a limited number of studies. Edible films and coatings may be regarded as feasible alternatives for carrying and delivering probiotics. Considering that packaging materials containing probiotics may enhance food stability (by controlling the growth of spoilage microorganisms by competition) and also contribute to the health of consumers, they may be considered both as active and potentially bioactive materials. The main features of the studies on films and coatings containing probiotics are summarized in Table 2.

\subsubsection{Studies focused on probiotic viability in films}

Traditionally, the systems intended to deliver probiotic cultures have both a conventional (pharmaceutical-related products) and a non-conventional (e.g. food-based products) approach (Vieira da Silva et al., 2016). Active edible films and coatings may present both aspects as their intake may be expected alongside a regular food product or they may act as exclusively a carrier instead, such as in oraldisintegrating films. Regardless of the mechanism, the major role (i.e. delivering health benefits) of probiotic-containing edible films and coating is played more or less efficiently depending upon their ability to provide viable bacteria to the gastrointestinal tract. The viability, stability, and survival of several probiotic strains under various conditions has been extensively investigated and reviewed (Corona-Hernandez et al., 2013; Dianawati, Mishra, \& Shah, 2015; Paseephol \& Sherkat, 2009; Ranadheera et al., 2015; Vinderola, Binetti, Burns, \& Reinheimer, 2011). Fewer though meaningful studies have focused on evaluating the viability of probiotic strains specifically in films in order to assess their stability in terms of active/bioactive properties. These are further discussed in this section.

Pullulan and various starches (from potato, tapioca, and corn) have been used to develop novel edible films incorporated with a mix of probiotic cultures (Lactobacillus reuteri ATCC 55730, L. rhamnosus GG ATCC 53103, and L. acidophilus DSM 20079) at an initial concentration of $12.9 \log \mathrm{CFUmL}^{-1}$ (Kanmani \& Lim, 2013). Treatments were tested with films prepared from pure pullulan and mixtures of different starches and pullulan, stored at 25 and $4{ }^{\circ} \mathrm{C}$. The probiotic viability in pure pullulan film was around $80 \%$ after 10 days of storage at $25^{\circ} \mathrm{C}$, decreasing to $35 \%$ after 20 days. Films incorporated with starches, however, presented decreased cell viability: the higher the starch content, the lower the viability. At $4{ }^{\circ} \mathrm{C}$, on the other hand, the viabilities were higher - near $90 \%$ for pullulan and pullulan/potato starch (75:25 weight ratio) films up to 30 days of storage.

Prebiotics, which may be defined as "the selectively fermented ingredients that allow specific changes, both in the composition and/or activity in the gastrointestinal microbiota that confers benefits upon host well-being and health" (Gibson, Probert, Loo, Rastall, \& Roberfroid, 2004), have also been incorporated into edible films to improve the stability of probiotic strains that had been added to the filmforming dispersions. Romano et al. (2014) prepared methylcellulose (MC) films containing two probiotic strains (Lactobacillus delbrueckii subsp. bulgaricus CIDCA 333 and Lactobacillus plantarum CIDCA 83114) and fructo-oligosaccharides (FOS) as a prebiotic. The bacterial strains were found to be completely embedded in the film matrix, whose integrity was not affected by the presence of these probiotic bacteria. Since FOS were found to present not only positive effects (protecting $L$. delbrueckii) but also negative effects (reducing the glass transition temperature of the films), the FOS concentrations were selected according to a balance between those effects. Films containing L. delbrueckii were then added with $3 \%(\mathrm{w} / \mathrm{v})$ of FOS, while films with $L$. plantarum were added with $1 \%$ of FOS. L. plantarum was found to be stable for longer periods at higher RH values, when compared to L. delbrueckii, which may be useful for practical applications. Similarly, inulin, chitosan 
Table 2

Bioactive films and coatings containing probiotic bacteria.

\begin{tabular}{|c|c|c|c|c|c|c|}
\hline $\begin{array}{l}\text { Biopolymeric } \\
\text { matrix }\end{array}$ & Probiotic & Other additives & Substrate & Viability & $\begin{array}{l}\text { Inhibition of } \\
\text { other species }\end{array}$ & Reference $^{*}$ \\
\hline $\begin{array}{l}\text { Alginate } \\
\text { Gellan }\end{array}$ & B. lactis Bb-12 & - & $\begin{array}{l}\text { Coatings on } \\
\text { fresh-cut apples } \\
\text { and papayas }\end{array}$ & $>6 \log$ cycles $\mathrm{CFU} \cdot \mathrm{g}^{-1}$ up to 10 days at $2{ }^{\circ} \mathrm{C}$ & - & (a) \\
\hline Caseinate & L. sakei & - & $\begin{array}{l}\text { Films on fresh } \\
\text { beef }\end{array}$ & $>6 \log$ cycles $\mathrm{CFU} \cdot \mathrm{cm}^{-2}$ up to 21 days at $4{ }^{\circ} \mathrm{C}$ & $\begin{array}{l}\text { L. } \\
\text { monocytogenes }\end{array}$ & (b) \\
\hline Alginate & $\begin{array}{l}\text { C. } \\
\text { maltaromaticum }\end{array}$ & - & $\begin{array}{l}\text { Films on smoked } \\
\text { salmon }\end{array}$ & $>7 \log$ cycles $\mathrm{CFU} \cdot \mathrm{cm}^{-2}$ up to 28 days at $4{ }^{\circ} \mathrm{C}$ & $\begin{array}{l}\text { L. } \\
\text { monocytogenes }\end{array}$ & (c) \\
\hline Gelatin & $\begin{array}{l}\text { L. acidophilus } \\
\text { B. bifidum }\end{array}$ & - & $\begin{array}{l}\text { Films and } \\
\text { coatings on hake } \\
\text { fish }\end{array}$ & $>8 \log$ cycles $\mathrm{CFU} \cdot \mathrm{g}^{-1}$ up to 6 days at $2{ }^{\circ} \mathrm{C}$ & 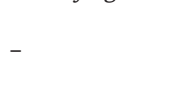 & (d) \\
\hline Agar & $\begin{array}{l}\text { L. paracasei } \\
\text { B. lactis }\end{array}$ & Green tea extract & $\begin{array}{l}\text { Films on hake } \\
\text { fillets }\end{array}$ & $>6 \log$ cycles $\mathrm{CFU} \cdot \mathrm{cm}^{-2}$ up to 15 days at $4{ }^{\circ} \mathrm{C}$ & $\begin{array}{l}\mathrm{H}_{2} \mathrm{~S} \text {-producing } \\
\text { microorganisms }\end{array}$ & (e) \\
\hline Methylcellulose & $\begin{array}{l}\text { L. delbrueckii } \\
\text { L. plantarum }\end{array}$ & Prebiotic: FOS & $\begin{array}{l}\text { Films, no } \\
\text { substrate }\end{array}$ & $\begin{array}{l}\text { Time for } 1 \text { log reduction }\left(11 \% \mathrm{RH}, 4^{\circ} \mathrm{C}\right): L \text {. } \\
\text { delbrueckii, } 45 \text { days; L. plantarum, } 90 \text { days }\end{array}$ & - & (f) \\
\hline $\begin{array}{l}\text { Pullulan } \\
\text { Pullulan/starch } \\
\text { blends }\end{array}$ & $\begin{array}{l}\text { L. rhamnosus, } L \text {. } \\
\text { reuteri, } L . \\
\text { acidophilus }\end{array}$ & - & $\begin{array}{l}\text { Films, no } \\
\text { substrate }\end{array}$ & $\begin{array}{l}\text { Highest viabilities for pullulan and } \\
\text { pullulan/potato starch }(75: 25) \text { : near } 90 \% \\
\text { viability up to } 30 \text { days at } 4{ }^{\circ} \mathrm{C} \text {. }\end{array}$ & - & (g) \\
\hline Gelatin & L. rhamnosus & $\begin{array}{l}\text { Prebiotics: inulin, polydextrose, } \\
\text { glucose-oligosaccharides, wheat } \\
\text { dextrin }\end{array}$ & $\begin{array}{l}\text { Films, no } \\
\text { substrate }\end{array}$ & $\begin{array}{l}\text { Time for } 1 \text { log reduction }\left(4{ }^{\circ} \mathrm{C}\right): 63 \text { days (gluco- } \\
\text { oligosaccharides) to } 100 \text { days (insulin) }\end{array}$ & - & (h) \\
\hline Alginate & & & & & & \\
\hline $\begin{array}{l}\text { Alginate/whey } \\
\text { protein } \\
\text { concentrate }\end{array}$ & L. rhamnosus & - & Coatings on bread & $\begin{array}{l}>10^{6} \mathrm{CFU} \cdot \mathrm{g}^{-1} \text { up to } 7 \text { days at room } \\
\text { temperature. }\end{array}$ & - & (i) \\
\hline $\begin{array}{l}\text { Hydroxypropyl } \\
\quad \text { methylcellulose } \\
\text { Isolate pea protein } \\
\text { Methylcellulose } \\
\text { Sodium caseinate }\end{array}$ & L. plantarum & Glycerol & $\begin{array}{l}\text { Films, no } \\
\text { substrate }\end{array}$ & $\begin{array}{l}\text { Highest viabilities for sodium caseinate: }>10^{5} \\
\mathrm{CFU} \cdot \mathrm{cm}^{-2} \text { up to } 30 \text { days at } 5{ }^{\circ} \mathrm{C} \text {. }\end{array}$ & L. innocua & (j) \\
\hline $\begin{array}{l}\text { Methylcellulose } \\
\quad(\mathrm{MC}) \\
\text { Sodium caseinate }\end{array}$ & $\begin{array}{l}\text { L. reuteri } \\
\text { L. acidophilus }\end{array}$ & Glycerol & $\begin{array}{l}\text { Films, no } \\
\text { substrate }\end{array}$ & $\begin{array}{l}\text { Highest viabilities for } \text { L. Acidophilus: }>10^{4} \\
\text { (sodium caseinate) and }>10^{3} \text { (MC) CFU } \cdot \mathrm{cm}^{-2} \\
\text { up to } 30 \text { days at } 5{ }^{\circ} \mathrm{C} \text {. }\end{array}$ & L. innocua & (k) \\
\hline
\end{tabular}

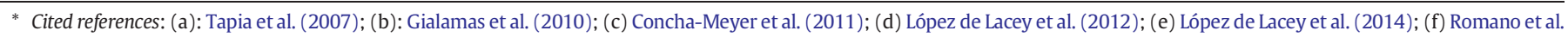
(2014); (g) Kanmani and Lim (2013); (h) Soukoulis et al. (2014a); (i) Soukoulis et al. (2014b); (j) Sánchez-González et al. (2013); (k) Sánchez-González et al. (2014).

oligosaccharide (COS), galacto-oligosaccharide (GtOS) and FOS have been added to maize starch-based edible films for prebiotic purposes and have been shown to promote the growth of the probiotic bacteria Bifidobacterium infantis ATCC 15697 and Lactobacillus fermentum ATCC 9398 (Tang et al., 2015). In addition to the prebiotic effect, these compounds have also affected the physical properties of the edible films, which have shown impaired tensile strength and boosted extensibility when compared to prebiotic-free (control) films. According to the authors, this plasticization effect may be attributed to the much smaller molecular weights of the prebiotics than that of starch.

Soukoulis, Behboudi-Jobbehdar, Yonekura, Parmenter, and Fisk (2014) developed gelatin films containing L. rhamnosus GG and four selected prebiotic components: inulin, polydextrose, gluco-oligosaccharides (GOS), and wheat dextrin. The prebiotics made the film structure more uniform. GOS were reported as the prebiotic that provided the best protection to the probiotic during film drying at $37{ }^{\circ} \mathrm{C}$, allowing the retention of $60 \%$ of cells, followed by polydextrose, which allowed 26\% cell retention during drying. Surprisingly, inulin and wheat dextrin presented a negative effect on bacterial survival. On the other hand, inulin was the most effective prebiotic agent to protect the probiotic during storage; while it took 63-83 days for the films with other prebiotics to have their probiotic population reduced by 1 $\log$ cycle, the same reduction occurred after 100 days for the film with inulin.

Starch (from rice and corn)-protein (bovine gelatin, sodium caseinate, and soy protein) edible films were added by L. rhamnosus GG and stored at fridge and room temperature (Soukoulis, Singh, Macnaughtan, Parmenter, \& Fisk, 2016). Both storage temperature and film composition were found to play a significant role in the viability and stability of the probiotic culture during the film-forming procedure as well as throughout storage. The loss of $L$. rhamnosus GG cells induced by film processing (i.e. solvent evaporation), for instance, was significantly lower in protein-based films than in their starch-based counterparts. Furthermore, rice starch and proteins were observed to act synergistically as to $L$. rhamnosus GG viability. Finally, film shelf life (threshold: 6 log viable $\mathrm{CFU} \cdot \mathrm{g}^{-1}$ ) was maintained until 27-96 and 15-24 days when stored at 4 and $25{ }^{\circ} \mathrm{C}$, respectively (Soukoulis et al., 2016).

Piermaria, Diosma, Aquino, Garrote, and Abraham (2015) incorporated L. plantarum and Kluyveromyces marxianus cells into glycerol-plasticized edible kefiran (a polysaccharide produced by lactic acid bacteria) films. While the authors demonstrated that the physical and optical properties of the films were nearly unchanged upon the addition of the probiotic cultures, the high susceptibility of the latter to acid was reduced by its inclusion into the polymer matrix. The film-forming procedure (casting at $37^{\circ} \mathrm{C}$ ) led to a slight decrease in the L. plantarum count, whereas that of the yeast remained constant. Furthermore, the viability of both microorganisms was maintained throughout storage at non-refrigerated temperature.

Coatings based on sodium alginate or alginate/whey protein concentrate (WPC) containing L. rhamnosus GG have been applied by Soukoulis, Yonekura et al. (2014) to bread, which was then air dried at $60{ }^{\circ} \mathrm{C}$ for $10 \mathrm{~min}$ or $180^{\circ} \mathrm{C}$ for $2 \mathrm{~min}$. The alginate/WPC coating resulted in higher viability of the probiotic strain throughout drying (76.3\%) when compared to the alginate coating (15.9\%), while the drying regime did not significantly affect the viability. The cell viability was considerably reduced during the initial $24 \mathrm{~h}$ of storage, then stabilized, and finally increased upon days 4-7 of storage. Differently from most other studies, this one included an in vitro digestion test for evaluating probiotic viability, and also defined the amount of probiotics to be delivered with a certain amount of food. Coated bread crust samples were submitted to in vitro digestion under simulated gastrointestinal conditions; the sample coated with alginate resulted in a lower viability loss $(0.7 \mathrm{log}$ 
$\left.\mathrm{CFU} \cdot \mathrm{g}^{-1}\right)$ than the sample coated with alginate/WPC (1.5-1.6 log $\left.\mathrm{CFU} \cdot \mathrm{g}^{-1}\right)$, that is to say, the alginate coating provided higher protection than alginate/WPC coating upon in vitro digestion. The probiotic level to be delivered by a bread slice (30-40 g) was calculated as being 7.6-9 log CFU (before digestion) and 6.5-6.9 log CFU (after in vitro digestion), meeting the required cell counts for the bread to be considered as probiotic.

\subsubsection{Studies focused on inhibitory activity against other microbial species}

Tapia et al. (2007) applied alginate and gellan edible coatings incorporated with $B$. lactis BB-12 on fresh-cut fruits (apple and papaya cylinders). Alginate or gellan film-forming solutions $(2 \% \mathrm{w} / \mathrm{v})$ incorporated with viable bifidobacteria were applied on the surface of the fresh-cut fruits. The results showed that, even if the counting of B. lactis Bb-12 in coatings usually decreased significantly upon 10 days of storage at $2{ }^{\circ} \mathrm{C}$ (with viability losses of up to $85 \%$ ), it was still greater than $10^{6}$ $\mathrm{CFU} \cdot \mathrm{g}^{-1}$ after 10 days. These results indicated that alginate and gellan are able to carry and hold probiotic microorganisms in a viable manner on fresh-cut fruits.

Gialamas, Zinoviadou, Biliaderis, and Koutsoumanis (2010) developed edible films from sodium caseinate incorporated with Lactobacillus sakei cells. Two techniques were used to add the probiotic strain into the caseinate matrix - i.e. direct incorporation to the film-forming solution or spraying on a pre-formed film. The films were applied to the surface of both a laboratory medium (tryptose soy agar, TSA) and a food model system (fresh beef) previously inoculated with L. monocytogenes. After the contact of the film with the surface of TSA at $4{ }^{\circ} \mathrm{C}$, the population of $L$. sakei grew rapidly, from an initial population of less than $10^{6}$ to $10^{7} \mathrm{CFU} \cdot \mathrm{cm}^{-2}$ within 4 days, regardless of the L. sakei addition technique. After 12 days of storage, films containing L. sakei presented a pathogen population decreased by 3 log cycles (in the case of films obtained from the probiotic-containing film-forming solution) or $3.6 \mathrm{log}$ cycles (in the case of the sprayed film). The L. monocytogenes level in fresh beef packed in films containing $L$. sakei and stored at $4{ }^{\circ} \mathrm{C}$ was reduced by $2 \log$ cycles when compared to the samples with the control film (without $L$. sakei). The counting of $L$. sakei was maintained above $10^{6} \mathrm{CFU} \cdot \mathrm{cm}^{-2}$ of film area for at least 21 days at $4^{\circ} \mathrm{C}$. Interestingly, sorbitol (used as a film plasticizer) was found to improve the viability of $L$. sakei, corroborating the role of polyols as protective agents for microbial cells upon storage at low water activity (Linders, de Jong, Meerdink, \& van't Riet, 1997). Some mechanisms have been proposed to explain these protective effects, such as lowering the phase transition temperature of dry membranes, maintaining the membrane fluidity, and protecting the protein structure in dry state (Leslie, Israeli, Lighthart, Crowe, \& Crowe, 1995; Santivarangkna, Naumann, Kulozik, \& Foerst, 2010).

Carnobacterium maltaromaticum is considered as a potential probiotic microorganism (Lauzon et al. 2014), commonly found in several fish species as part of their normal intestinal flora. C. maltaromaticum isolated from rainbow trout (Oncorhynchus mykiss) presented activity against Gram-positive and Gram-negative pathogens, as well as a broad spectrum of antibiotic resistance (Kim \& Austin, 2008). Concha-Meyer, Schöbitz, Brito, and Fuentes (2011) developed a film based on alginate incorporated with viable $C$. maltaromaticum to preserve smoked salmon at refrigeration temperatures. The films were applied on the surface of smoked salmon pieces and presented bacteriostatic effect against $L$. monocytogenes - which had been previously inoculated to a final concentration of $10^{4} \mathrm{CFU} \cdot \mathrm{cm}^{-2}$ - over 28 days at $4{ }^{\circ} \mathrm{C}$. The authors indicated that these results exceed the industrial shelf-life requirements for smoked salmon, demonstrating that the developed films inhibited $L$. monocytogenes on salmon under specified conditions.

The probiotic bacteria L. acidophilus and Bifidobacterium bifidum were inoculated into edible gelatin coatings and films for preserving hake fish (Merluccius merluccius) (López de Lacey, LópezCaballero, Gómez-Estaca, Gómez-Guillén, \& Montero, 2012). The counts of $L$. acidophilus and B. bifidum, both on film-forming solutions and films presented an initial concentration of $10^{9}$ $\mathrm{CFU} \cdot \mathrm{mL}^{-1}$, with both probiotic cultures remaining constant for 6 days at $2{ }^{\circ} \mathrm{C}$. The application of gelatin coatings (with or without B. bifidum) to hake cuts resulted in a significant reduction of the population of $\mathrm{H}_{2} \mathrm{~S}$-producing microorganisms, presumably Shewanella putrefaciens, when compared to the uncoated hake. Thus, the study was not conclusive about whether the reduction in the growth of $\mathrm{H}_{2} \mathrm{~S}$-producing microorganisms resulted from an inhibitory effect from the probiotic bacteria or from the coating itself. In a second step of the study, hake wrapped with films were submitted to a low-level high pressure treatment (200 MPa for $10 \mathrm{~min}$ at $20^{\circ} \mathrm{C}$ ), in order to reduce the Gram-negative flora while affecting less the Gram-positive bacteria (including those incorporated in the film), and also to avoid sensory changes of fish. The counts of total bacteria and $\mathrm{H}_{2} \mathrm{~S}$ producers were reduced by the high pressure treatment, while both counts of lactic acid bacteria and bifidobacteria were unaffected by it. The results suggest that the combination of edible films containing bifidobacteria with a high pressure treatment is promising for the preservation of fish and other products whose spoilage is determined by Gram-negative bacteria.

The same group conducted another study (López de Lacey, López-Caballero, \& Montero, 2014) incorporating green tea extract and two probiotic strains (Lactobacillus paracasei L26 and B. lactis B94) into agar-based films that were then applied to hake fillets previously inoculated with $S$. putrefaciens and Photobacterium phosphoreum $\left(10^{3}-10^{4} \mathrm{CFU} \cdot \mathrm{g}^{-1}\right)$. The probiotic bacteria migrated to the fish, resulting in proliferation of lactic acid bacterial populations. The films containing probiotics and/or green tea extract resulted in decreased chemical spoilage indicators (total volatile bases and trimethylamine nitrogen, and $\mathrm{pH}$ changes) and reduced counts of $\mathrm{H}_{2} \mathrm{~S}$-producing microorganisms, when compared to hake coated with a film without those agents or uncoated hake. The combination of probiotics with green tea extract in films resulted in better chemical and microbial stabilities when compared to films containing just probiotics, leading to a shelf-life extension of at least a week.

Different biopolymers, such as sodium caseinate, pea protein, MC and hydroxypropyl methylcellulose (HPMC), have been tested for incorporating L. plantarum in edible films based on polysaccharide or protein (Sánchez-González, Quintero Saavedra, \& Chiralt, 2013). According to Sánchez-González et al. (2013), proteinbased films allowed higher L. plantarum viability, with bacteriocin production being slower than in cellulose-based films, which in turn presented higher bacteriocin production. In addition, HPMC and MC films incorporated with $L$. plantarum completely inhibited Listeria innocua growth during the first 8 days of storage at $5{ }^{\circ} \mathrm{C}$, indicating that these films were effective carriers of $L$. plantarum.

Sodium caseinate and MC have been used to develop biopolymeric films incorporated with $L$. acidophilus and L. reuteri (Sánchez-González, Quintero Saavedra, \& Chiralt, 2014). The survival of both probiotic cultures in biopolymeric films and their antimicrobial potential against L. innocua were assessed. SánchezGonzález et al. (2014) reported that the viability of L. acidophilus was greater than that of $L$. reuteri in both polymeric matrices. $L$. reuteri presented a significant reduction of its initial population during the first week of storage, indicating that this strain is more sensitive to the stress suffered during storage. Moreover, when comparing both hydrocolloid matrices, sodium caseinate was a more favorable environment than MC for microorganism survival, reaching viability on the order of $10^{7} \mathrm{CFU} \cdot \mathrm{cm}^{-2}$ after 3 days of storage. With regard to the antilisterial activity, the best results were obtained with MC films after 3 days of storage. No differences were observed among the different films after a longer storage time, though $L$. innocua growth was reduced by approximately 1.5 $\log$ cycles compared to the control after 12 days of storage. 
3.3. Food matrix consideration and potential for probiotic films and coatings applications

Traditionally, dairy food products have been used as carriers of probiotic microorganisms. Recently, other food matrices with a different origin have been tested with the same purpose, such as meat, traditional cereal-based beverages and chocolate (Fig. Fig. 3).

The physicochemical as well as functional properties of these food matrices have a key role in ensuring probiotic viability. In this regard, Ranadheera et al. (2010) have indicated that food formulation can be used to favor probiotic viability, with concentration of fat, protein, carbohydrates and their interactions as the main factors that support probiotic microbial growth.

Thus, properly formulated food can be an effective carrier of probiotic by two means:

- Direct probiotic delivery through the formulated food matrix;

- Indirect probiotic delivery, when formulated food constitutes the polymeric matrix for packaging material development. In this context, the developed packaging material is edible and should present satisfactory conditions for probiotic viability.

Moreover, food preservation is commonly associated with chemical additive and good manufacturing and storing practices. However, active food packaging incorporated with natural compounds has emerged as a potential alternative to chemical preservative for food preservation. Previous research studies (Tapia et al., 2007; Gialamas et al., 2010; Concha-Meyer et al., 2011; López de Lacey et al., 2012; López de Lacey et al., 2014; Soukoulis et al., 2014b) have shown the potential food that might be preserved by the application of probiotic films and coatings include fish, fresh meat, fruits and baked food products, such as bread (Fig. Fig. 2).

In any case, whether the probiotic is incorporated into the formulated food or into the packaging material, the carrier should protect probiotic microorganisms against external factors, as well as the effect of the gastrointestinal and bile conditions (Desobry \& Debeaufort (2012).

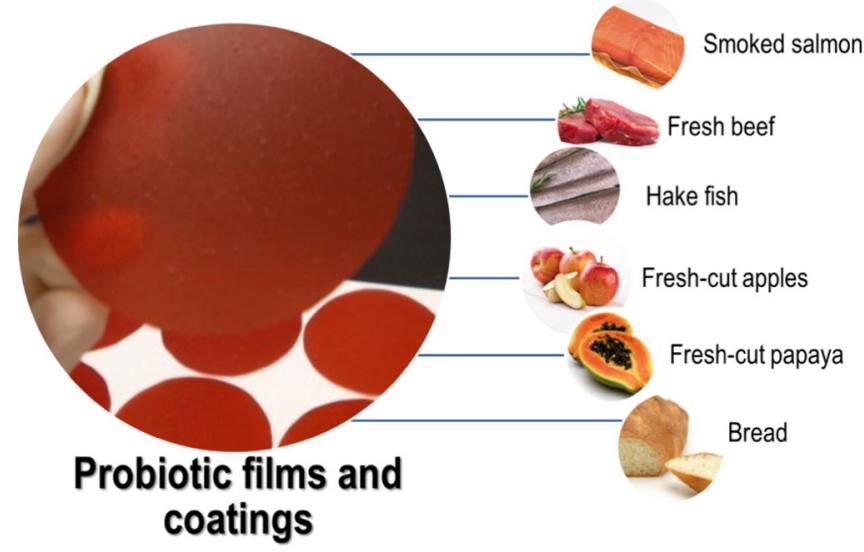

Fig. 3. Indirect probiotic delivery: Potential food to be considered for probiotic films and coatings applications.

\section{Regulations related to probiotics and active food packaging}

In the United States, regulatory requirements are determined by the intended use of probiotics, whether as a drug or as a dietary supplement. Although probiotics fall into virtually all product categories regulated by the FDA, there is still no pathway to deal specifically with probiotics. Instead, probiotic products are regulated based on the product category into which they fall, such as food or food additive (Hoffmann et al., 2012, reviewed in 2016; U.S. Food and Drug Administration, 2016). For example, only premarket notification is required if the probiotic product is intended to be used as a dietary supplement (Venugopalan, Shriner, \& Wong-Beringer, 2010). The probiotic product must go through a regulatory process, however, if the probiotic is intended to be used as a drug.

Most probiotic microorganisms have a long-lasting history of safe use as food components, so safety evaluation does not denote a hurdle to be overcome (van Loveren, Sanz, \& Salminen, 2012). Among them, numerous microorganisms have been qualified with the presumption of safety (QPS) status for food applications (EFSA, 2010; Leuschner et al., 2010) by the European Food Safety Authority (EFSA) and have

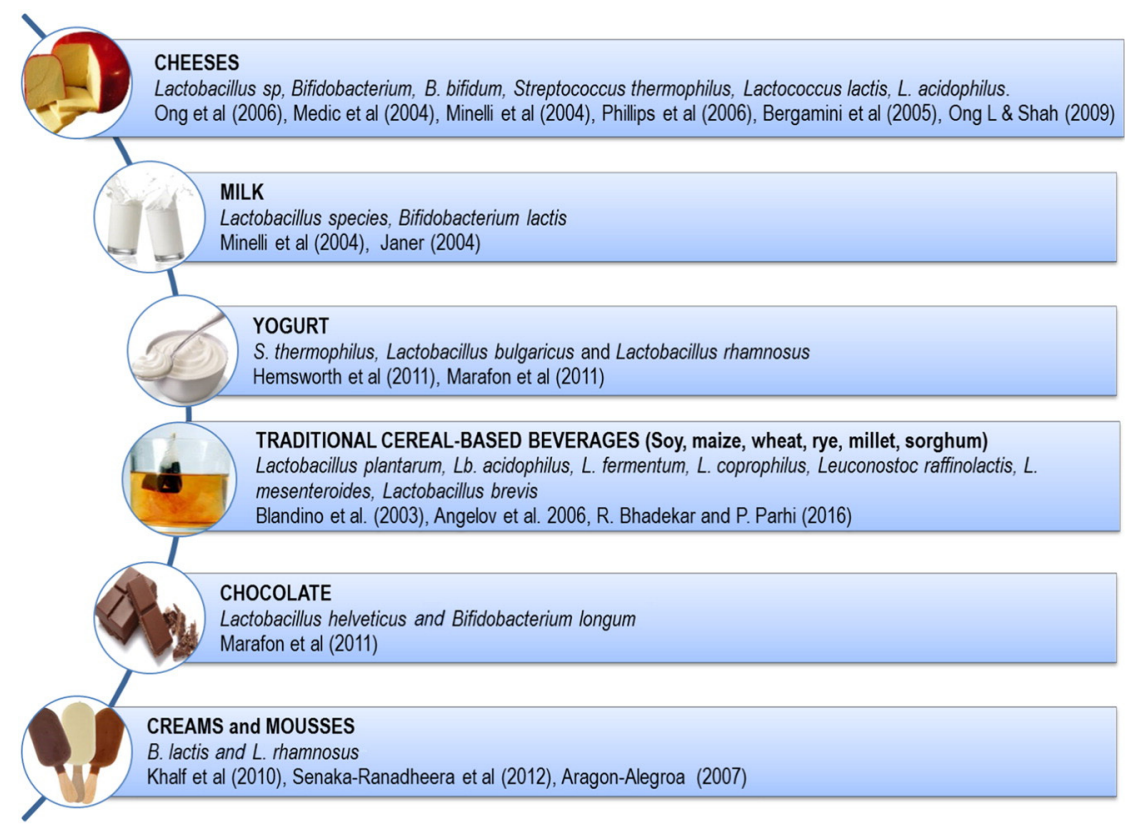

Fig. 2. Direct probiotic delivery through the formulated food matrix. 
been classified as generally regarded as safe (GRAS) by the U.S. Food and Drug Administration (FDA, 2016).

On the other hand, the European legislation is more conservative, as described by Miquel et al. (2015) and Glanville, King, Guarner, Hill, \& Sanders (2015). The term "probiotic" is not regulated, since the designation implies a beneficial health effect, and should be considered a health claim by itself. On one hand, many microorganisms currently used in food fermentation have a long history of safe use in the European Union (EU). On the other hand, foods containing microorganisms which have not had a traditional use in food production in Europe before 1997 are considered as novel foods, whose legislation is currently under Regulation (EC) No 2015/2283 (European Commission, 2015). A novel food should be subjected to an in-depth characterization and safety assessment should be done before commercialization on the European market. According to the EU legislation on health claims, based on Regulation (EC) No 2006/1924 (European Commission, 2006), the communication of any health claim to consumers (such as categorizing a food product as "probiotic") may only be made after authorization by the European Commission, which requires a favorable opinion from the EFSA.

In Brazil, the "Technical regulation of bioactive substances and probiotics isolates with alleged of functional or health properties" (RDC No 2/2002 ANVISA) is used as a guideline for the safety assessment, registration and commercialization of bioactive substances and probiotics with claims of health properties (ANVISA, 2002). However, Brazilian regulation, similar to those of USA and Europe, does not provide a specific law for edible materials containing probiotic microorganisms.

\section{Final considerations}

The global probiotics market has been constantly growing due to consumer concerns regarding healthy diets and wellness. In this context, the consumption of probiotic food products has been constantly increasing. Another trend in food technology is the growing use of edible films and coatings, acting as packaging aids towards extending food stability.

Incorporating probiotics into edible films and coatings has been proposed as an emerging technology which has generated a number of studies in the last decade. The probiotic films and coatings would be considered as bioactive materials, in the sense that they may promote health benefits to the consumer, due to their potential probiotic properties. Concomitantly, probiotic films and coatings may also be considered as active, in the sense that they may promote an active role in extending food stability, which is based on the premise that probiotic bacteria present competitive effects against spoilage microorganisms. However, although the incorporation of probiotic bacteria into an edible material is expected to be primarily motivated by the promotion of health benefits to the consumers, those effects have not been approached in those studies. Instead, developed studies were focused on either evaluating the viability of the probiotic strains (in order to establish if the films are suitable to keep the probiotics alive throughout processing and storage) and/or studying the effects of films or coatings on growth of spoiling or pathogenic microorganisms, based on the premise that probiotic bacteria present competitive effects against spoilage bacteria. Just one study (Soukoulis, Yonekura, et al., 2014) advanced in evaluating cell viability upon simulated gastrointestinal conditions, and also established the level of probiotic to be delivered by a defined portion of the food product. Nevertheless, more studies are required to evaluate two important aspects of any product to be considered as probiotic: (a) the ability of probiotic strains contained in edible films or coatings to survive the transit through the upper gastrointestinal tract, and (b) the release of probiotic strains from the matrices to colonize the intestine. Those kinds of information are essential to establish whether the materials may really be regarded as probiotic edible films and coatings, or just active materials with antimicrobial effects to extend food stability.

\section{Acknowledgements}

PJP Espitia thanks the National Bureau for the Development of Science and Technology in Colombia (COLCIENCIAS) and Universidad del Atlántico. RA Batista thanks the support provided by the National Counsel of Technological and Scientific Development (CNPq). CG Otoni thanks the financial support of São Paulo Research Foundation (FAPESP, grant \# 2014/23098-9).

\section{References}

Ahvenainen, R. (2003). Novel food packaging techniques. Cambridge, UK: Woodhead Publishing Limited.

Alegre, I., Viñas, I., Usall, J., Anguera, M., \& Abadias, M. (2011). Microbiological and physicochemical quality of fresh-cut apple enriched with the probiotic strain Lactobacillus rhamnosus GG. Food Microbiology, 28, 59-66.

Altamirano-Fortoul, R., Moreno-Terrazas, R., Quezada-Gallo, A., \& Rosell, C. M. (2012). Viability of some probiotic coatings in bread and its effect on the crust mechanical properties. Food Hydrocolloids, 29, 166-174.

Angelov, A., Gotcheva, V., Kuncheva, R., \& Hristozova, T. (2006). Development of a new oat-based probiotic drink. International Journal of Food Microbiology, 112(1), 75-80.

ANVISA (2002). Resolução RDC N. ${ }^{\circ} 2$, de 7 de Janeiro de 2002. Regulamento técnico de substâncias bioativas e probióticos isolados com alegação de propriedades funcional e ou de saúde. Brasília: ANVISA.

Appendini, P., \& Hotchkiss, J. H. (1997). Immobilization of lysozyme on food contact polymers as potential antimicrobial films. Packaging Technology and Science, 10, 271-279.

Aragon-Alegro, L. C., Alarcon Alegro, J. H., Roberta Cardarelli, H., Chih Chiu, M., \& Isay Saad, S. M. (2007). Potentially probiotic and synbiotic chocolate mousse. LWT - Food Science and Technology, 40(4), 669-675.

Aureli, P., Capurso, L., Castellazzi, A. M., Clerici, M., Giovannini, M., Morelli, L.,... Zuccotti, G V. (2011). Probiotics and health: An evidence-based review. Pharmacological Research, 63, 366-376.

Balthazar, C. F., Conte Júnior, C. A., Moraes, J., Costa, M. P., Raices, R. S. L., Franco, R. M., Silva, A. C. O. (2016). Physicochemical evaluation of sheep milk yogurts containing different levels of inulin. Journal of Dairy Science, 99(6), 4160-4168.

Batista, A. L. D., Silva, R., Cappato, L. P., Almada, C. N., Garcia, R. K. A., Silva, M. C., ... Cruz, A. G. (2015). Quality parameters of probiotic yogurt added to glucose oxidase compared to commercial products through microbiological, physical-chemical and metabolic activity analyses. Food Research International, 77(3), 627-635.

Bergamini, C. V., Hynes, E. R., Quiberoni, A., Suárez, V. B., \& Zalazar, C. A. (2005). Probiotic bacteria as adjunct starters: influence of the addition methodology on their survival in a semi-hard Argentinean cheese. Food Research International, 38(5), 597-604.

Bhadekar, R., \& Parhi, P. (2016). Non-dairy functional foods: Potential of probiotics. In N. Garg, M. S. Abdel-Aziz, \& A. Aeron (Eds.), Microbes in Food and Health (pp. 1-27). Cham: Springer International Publishing.

Blandino, A., Al-Aseeri, M. E., Pandiella, S. S., Cantero, D., \& Webb, C. (2003). Cereal-based fermented foods and beverages. Food Research International, 36(6), 527-543.

Botrel, D. A. Soares, N. F. F. Espitia, P. J. P. Sousa, S. \& Renhe, I. R. T. (2010). Avaliação de filme incorporado com óleo essencial de orégano para conservação de pizza pronta. Revista Ceres, 57, 283-291.

Burey, P., Bhandari, B. R., Howes, T., \& Gidley, M. J. (2009). Gel particles from spray-dried disordered polysaccharides. Carbohydrate Polymers, 76, 206-213.

Clarke, G., Cryan, J. F., Dinan, T. G., \& Quigley, E. M. (2012). Review article: probiotics for the treatment of irritable bowel syndrome - focus on lactic acid bacteria. Alimentary Pharmacology and Therapeutics, 35, 403-413.

Coghetto, C. C., Brinques, G. B., Siqueira, N. M., Pletsch, J., Soares, R. M. D., \& Ayub, M. A. Z (2016). Electrospraying microencapsulation of Lactobacillus plantarum enhances cell viability under refrigeration storage and simulated gastric and intestinal fluids. Journal of Functional Foods, 24, 316-326.

Concha-Meyer, A., Schöbitz, R., Brito, C., \& Fuentes, R. (2011). Lactic acid bacteria in an alginate film inhibit Listeria monocytogenes growth on smoked salmon. Food Control, 22 485-489.

Corona-Hernandez, R. I., Álvarez-Parrilla, E., Lizardi-Mendoza, J., Islas-Rubio, A. R., de la Rosa, L. A., \& Wall-Medrano, A. (2013). Structural stability and viability of microencapsulated probiotic bacteria: A review. Comprehensive Reviews in Food Science and Food Safety, 12(6), 614-628.

Cruz, A. G., Castro, W. F., Faria, J. A. F., Lollo, P. C. B., Amaya-Farfán, J., Freitas, M. Q., .. Godoy, H. T. (2012). Probiotic yogurts manufactured with increased glucose oxidase levels: Postacidification, proteolytic patterns, survival of probiotic microorganisms, production of organic acid and aroma compounds. Journal of Dairy Science, 95(5), 2261-2269.

da Cruz, A. G., Faria, J. D. F., \& Van Dender, A. G. F. (2007). Packaging system and probiotic dairy foods. Food Research International, 40, 951-956.

Dantas, A. B., Jesus, V. F., Silva, R., Almada, C. N., Esmerino, E. A., Cappato, L. P., ... Cruz, A. G. (2016). Manufacture of probiotic Minas Frescal cheese with Lactobacillus casei Zhang. Journal of Dairy Science, 99(1), 18-30. 
de Prisco, A., \& Mauriello, G. (2016). Probiotication of foods: A focus on microencapsulation tool. Trends in Food Science E Technology, 48, 27-39.

Dianawati, D., Mishra, V., \& Shah, N. P. (2015). Survival of microencapsulated probiotic bacteria after processing and during storage: A review. Critical Reviews in Food Science and Nutrition, 56(10), 1685-1716.

Esmerino, E. A., Cruz, A. G., Pereira, E. P. R., Rodrigues, J. B., Faria, J. A. F., \& Bolini, H. M. A. (2013). The influence of sweeteners in probiotic Petit Suisse cheese in concentrations equivalent to that of sucrose. Journal of Dairy Science, 96(9), 5512-5521.

Esmerino, E. A., Paixão, J. A., Cruz, A. G., Garitta, L., Hough, G., \& Bolini, H. M. A. (2015). Survival analysis: A consumer-friendly method to estimate the optimum sucrose level in probiotic petit suisse. Journal of Dairy Science, 98(11), 7544-7551.

Espírito Santo, A. P., Perego, P., Converti, A., \& Oliveira, M. N. (2011). Influence of food matrices on probiotic viability - A review focusing on the fruity bases. Trends in Food Science \&' Technology, 22, 377-385.

Espitia, P. J. P., Soares, N. F. F., Botti, L. C. M., \& Silva, W. A. (2011). Effect of essential oils in the properties of cellulosic active packaging. Macromolecular Symposia, 299-300 199-205.

Espitia, P. J. P., Du, W. -X., Avena-Bustillos, R. J., Soares, N. F. F., \& McHugh, T. H. (2013) Edible films from pectin: Physical-mechanical and antimicrobial properties - A review. Food Hydrocolloids, 35, 287-296.

Espitia, P. J. P., Otoni, C. G., \& Soares, N. F. F. (2016). Pediocin Applications in Antimicrobial Food Packaging Systems. In J. Barros-Velázquez (Ed.), Antimicrobial Food Packaging (pp. 445-454). San Diego: Academic Press.

Etchepare, M. D., Barin, J. S., Cichoski, A. J., Jacob-Lopes, E., Wagner, R., Fries, L. L. M., \& de Menezes, C. R. (2015). Microencapsulation of probiotics using sodium alginate. Ciencia Rural, 45, 1319-1326.

European Commission (2006). Regulation (EC) No 2006/1924 of the European Parliament and of the Council of 20 December 2006 on nutrition and health claims made on foods. Retrieved from http://eur-lex.europa.eu/legal-content/EN/TXT/PDF/?uri=CELEX: 02006R1924-20121129\&from $=\mathrm{EN}$

European Commission (2015). Regulation (EC) No 2015/2283 of the European Parliament and of the Council of 25 November 2015 on novel foods. Retrieved from http://eurlex.europa.eu/legal-content/EN/TXT/?qid=1475464789986\&uri=CELEX: 32015R2283

European Food Safety Authority (EFSA) Panel on Biological Hazards (2010H). Scientific opinion on the maintenance of the list of QPS biological agents intentionally added to food and feed. EFSA Journal, 10, 1-84.

Fávaro-Trindade, C. S., \& Grosso, C. R. F. (2002). Microencapsulation of L. acidophilus (La$05)$ and $B$. lactis (Bb-12) and evaluation of their survival at the $\mathrm{pH}$ values of the stomach and in bile. Journal of Microencapsulation, 19, 485-494.

Favaro-Trindade, C. S., Pinho, S. C. d., \& Rocha, G. A. (2008). Revisão: Microencapsulação de ingredientes alimentícios. Brazilian Journal of Food Technology, 11, 103-112.

Felicio, T. L., Esmerino, E. A., Vidal, V. A. S., Cappato, L. P., Garcia, R. K. A., Cavalcanti, R. N., .. Cruz, A. G. (2016). Physico-chemical changes during storage and sensory acceptance of low sodium probiotic Minas cheese added with arginine. Food Chemistry, 196 628-637.

Fernandes, M. S., Cruz, A. G., Dias Arroyo, D. M., Faria, J. d. A. F., Cristianini, M., \& Sant'Ana A. S. (2013). On the behavior of Listeria innocua and Lactobacillus acidophilus co-inoculated in a dairy dessert and the potential impacts on food safety and product's functionality. Food Control, 34(2), 331-335.

Food and Agriculture Organization (FAO) of the United Nations (2001o). Health and nutritional properties of probiotics in food including powder milk with live lactic acid bacteria. Córdoba, Argentina: World Health Organization.

Food and Agriculture Organization (FAO) of the United Nations (2002o). Guidelines for the evaluation of probiotics in food. London, Canada: World Health Organization.

Gálvez, A., Abriouel, H., López, R. L., \& Omar, N. B. (2007). Bacteriocin-based strategies for food biopreservation. International Journal of Food Microbiology, 120, 51-70.

Gialamas, H., Zinoviadou, K. G., Biliaderis, C. G., \& Koutsoumanis, K. P. (2010). Development of a novel bioactive packaging based on the incorporation of Lactobacillus sakei into sodium-caseinate films for controlling Listeria monocytogenes in foods. Food Research International, 43, 2402-2408.

Gibson, G. R., Probert, H. M., Loo, J. V., Rastall, R. A., \& Roberfroid, M. B. (2004). Dietary modulation of the human colonic microbiota: updating the concept of prebiotics. Nutrition Research Reviews, 17, 259-275.

Glanville, J., King, S., Guarner, F., Hill, C., \& Sanders, M. E. (2015). A review of the systematic review process and its applicability for use in evaluating evidence fo rhealth claims on probiotic foods in the European Union. Nutrition Journal, $14,16$.

Gomes, A. A., Braga, S. P., Cruz, A. G., Cadena, R. S., Lollo, P. C. B., Carvalho, C., ... Bolini, H. M. A. (2011). Effect of the inoculation level of Lactobacillus acidophilus in probiotic cheese on the physicochemical features and sensory performance compared with commercial cheeses. Journal of Dairy Science, 94(10), 4777-4786.

Gomez-Mascaraque, L. G., Morfin, R. C., Pérez-Masiá, R., Sanchez, G., \& Lopez-Rubio, A (2016). Optimization of electrospraying conditions for the microencapsulation of probiotics and evaluation of their resistance during storage and in-vitro digestion. LWT - Food Science and Technology, 69, 438-446

Granato, D., Branco, G. F., Nazzaro, F., Cruz, A. G., \& Faria, J. A. F. (2010). Functional foods and nondairy probiotic food development: Trends, concepts, and products. Comprehensive Reviews in Food Science and Food Safety, 9, 292-302.

Guérin, D., Vuillemard, J. -C., \& Subirade, M. (2003). Protection of bifidobacteria encapsulated in polysaccharide-protein gel beads against gastric juice and bile. Journal of Food Protection, 66, 2076-2084.

Hamilton-Miller, J. M. T., Gibson, G. R., \& Bruck, W. (2003). Some insights into the derivation and early uses of the word 'probiotic'. British Journal of Nutrition, 90, 845.

Han, J. H. (2005). Antimicrobial packaging systems. In H. H. Jung (Ed.), Innovations in Food Packaging (pp. 80-107). London: Academic Press.
Hempel, S., Newberry, S. J., Maher, A. R., Wang, Z., Miles, J. N., Shanman, R., ... Shekelle, P. G. (2012). Probiotics for the prevention and treatment of antibiotic-associated diarrhea: A systematic review and meta-analysis. JAMA, 307, 1959-1969.

Hoffmann, D. E., Fraser, C. M., Palumbo, F., Ravel, J., Rowthorn, V., \& Schwartz, J. (2012). Federal regulation of probiotics: An analysis of the existing regulatory framework and recommendations for alternative frameworks. Retrieved from http://www. law.umaryland.edu/programs/health/events/probiotics/documents/ FinalWhitePaper.pd

Huis Veld, J. H. J. I. T., \& Havenaar, R. (1991). Probiotics and health in man and animal. Journal of Chemical Technology \& Biotechnology, 51, 562-567.

Janer, C., Peláez, C., \& Requena, T. (2004). Caseinomacropeptide and whey protein concentrate enhance Bifidobacterium lactis growth in milk. Food Chemistry, 86(2), 263-267.

Jesus, A. L. T., Fernandes, M. S., Kamimura, B. A., Prado-Silva, L., Silva, R., Esmerino, E. A., ... Sant'Ana, A. S. (2016). Growth potential of Listeria monocytogenes in probiotic cottage cheese formulations with reduced sodium content. Food Research International, $81,180-187$

Kanmani, P., \& Lim, S. T. (2013). Development and characterization of novel probiotic-residing pullulan/starch edible films. Food Chemistry, 141, 1041-1049.

Khalf, M., Dabour, N., kheadr, E., \& Fliss, I. (2010). Viability of probiotic bacteria in maple sap products under storage and gastrointestinal conditions. Bioresource Technology, 101(20), 7966-7972.

Kim, D. H., \& Austin, B. (2008). Characterization of probiotic carnobacteria isolated from rainbow trout (Oncorhynchus mykiss) intestine. Letters in Applied Microbiology, 47, 141-147.

Krasaekoopt, W. (2013). Microencapsulation of probiotics in hydrocolloid gel matrices: A review. Agro FOOD Industry HiTech, 24, 1-11.

Krasaekoopt, W., Bhandari, B., \& Deeth, H. (2003). Evaluation of encapsulation techniques of probiotics for yoghurt. International Dairy Journal, 13, 3-13.

Lauzon, H. L., Pérez-Sánchez, T., Merrifield, D. L., Ringø, E., \& Balcázar, J. L. (2014). Probiotic applications in cold water fish species. Aquaculture Nutrition. John Wiley \& Sons, Ltd.

Leslie, S. B., Israeli, E., Lighthart, B., Crowe, J. H., \& Crowe, L. M. (1995). Trehalose and sucrose protect both membranes and proteins in intact bacteria during drying. Applied and Environmental Microbiology, 61, 3592-3597.

Leuschner, R. G. K., Robinson, T. P., Hugas, M., Cocconcelli, P. S., Richard-Forget, F., Klein, G., ... von Wright, A. (2010). Qualified presumption of safety (OPS): a generic risk assessment approach for biological agents notified to the European Food Safety Authority (EFSA). Trends in Food Science \& Technology, 21, 425-435.

Li, B. -Z., Wang, L. -J., Li, D., Bhandari, B., Li, S. -J., Lan, Y., ... Mao, Z. -H. (2009). Fabrication of starch-based microparticles by an emulsification-crosslinking method. Journal of Food Engineering, 92, 250-254.

Li, R., Zhang, Y., Polk, D. B., Tomasula, P. M., Yan, F., \& Liu, L. (2016a). Preserving viability of Lactobacillus rhamnosus GG in vitro and in vivo by a new encapsulation system. Journal of Controlled Release, 230, 79-87.

Li, R., Zhang, Y., Polk, D. B., Tomasula, P. M., Yan, F., \& Liu, L. (2016b). Preserving viability of Lactobacillus rhamnosus GG in vitro and in vivo by a new encapsulation system. Journal of Controlled Release, 230, 79-87.

Linders, L. J. M., de Jong, G. I. W., Meerdink, G., \& van't Riet, K. (1997). Carbohydrates and the dehydration inactivation of Lactobacillus plantarum: The role of moisture distribution and water activity. Journal of Food Engineering, 31, 237-250.

Lollo, P. C. B., Cruz, A. G., Morato, P. N., Moura, C. S., Carvalho-Silva, L. B., Oliveira, C. A. F., ... Amaya-Farfan, J. (2012). Probiotic cheese attenuates exercise-induced immune suppression in Wistar rats. Journal of Dairy Science, 95(7), 3549-3558.

Lollo, P. C. B., de Moura, C. S., Morato, P. N., Cruz, A. G., Castro, W. d. F., Betim, C. B., ... Amaya-Farfan, J. (2013). Probiotic yogurt offers higher immune-protection than probiotic whey beverage. Food Research International, 54(1), 118-124.

Lollo, P. C. B., Morato, P. N., de Moura, C. S., de Oliveira, M. M., Cruz, A. G., Faria, J. d. A. F., Cristianini, M. (2015a). Ultra-high temperature plus dynamic high pressure processing: An effective combination for potential probiotic fermented milk processing which attenuate exercise-induced immune suppression in Wistar rats. Journal of Functional Foods, 14, 541-548.

Lollo, P. C. B., Morato, P. N., Moura, C. S., Almada, C. N., Felicio, T. L., Esmerino, E. A., ... Cruz, A. G. (2015b). Hypertension parameters are attenuated by the continuous consumption of probiotic Minas cheese. Food Research International, 76(3), 611-617.

López de Lacey, A. M., López-Caballero, M. E., Gómez-Estaca, J., Gómez-Guillén, M. C., \& Montero, P. (2012). Functionality of Lactobacillus acidophilus and Bifidobacterium bifidum incorporated to edible coatings and films. Innovative Food Science $\mathcal{E}$ Emerging Technologies, 16, 277-282.

López de Lacey, A. M., López-Caballero, M. E., \& Montero, P. (2014). Agar films containing green tea extract and probiotic bacteria for extending fish shelf-life. LWT - Food Science and Technology, 55, 559-564.

Lopez-Rubio, A., Gavara, R., \& Lagaron, J. M. (2006). Bioactive packaging: Turning foods into healthier foods through biomaterials. Trends in Food Science E' Technology, 17, 567-575.

Majeed, M., Majeed, S., Nagabhushanam, K., Natarajan, S., Sivakumar, A., \& Ali, F. (2016). Evaluation of the stability of Bacillus coagulans MTCC 5856 during processing and storage of functional foods. International Journal of Food Science and Technology, 51(4), 894-901.

Marafon, A. P., Sumi, A., Alcântara, M. R., Tamime, A. Y., \& Nogueira de Oliveira, M. (2011). Optimization of the rheological properties of probiotic yoghurts supplemented with milk proteins. LWT - Food Science and Technology, 44(2), 511-519.

Marco, M. L., Pavan, S., \& Kleerebezem, M. (2006). Towards understanding molecular modes of probiotic action. Current Opinion in Biotechnology, 17, 204-210.

Martín, M. J., Lara-Villoslada, F., Ruiz, M. A., \& Morales, M. E. (2015). Microencapsulation of bacteria: A review of different technologies and their impact on the probiotic effects. Innovative Food Science \& Emerging Technologies, 27, 15-25. 
Martins, E. M. F., Ramos, A. M., Vanzela, E. S. L., Stringheta, P. C., de Oliveira Pinto, C. L., \& Martins, J. M. (2013). Products of vegetable origin: A new alternative for the consumption of probiotic bacteria. Food Research International, 51, 764-770.

Mattila-Sandholm, T., Blum, S., Collins, J. K., Crittenden, R., de Vos, W., Dunne, C., ... von Wright, A. (1999). Probiotics: Towards demonstrating efficacy. Trends in Food Science E' Technology, 10, 393-399.

Medici, M., Vinderola, C. G., \& Perdigón, G. (2004). Gut mucosal immunomodulation by probiotic fresh cheese. International Dairy Journal, 14(7), 611-618.

Miquel, S., Beaumont, M., Martín, R., Langella, P., Braesco, V., \& Thomas, M. (2015). A proposed framework for an appropriate evaluation scheme for microorganisms as novel foods with a health claim in Europe. Microbial Cell Factories, 14, 48

Mirzaei, H., Pourjafar, H., \& Homayouni, A. (2012). Effect of calcium alginate and resistant starch microencapsulation on the survival rate of Lactobacillus acidophilus La5 and sensory properties in Iranian white brined cheese. Food Chemistry, 132, 1966-1970.

Nguyen, H. -T., Truong, D. -H., Kouhoundé, S., Ly, S., Razafindralambo, H., \& Delvigne, F. (2016). Biochemical engineering approaches for increasing viability and functionality of probiotic bacteria. International Journal of Molecular Sciences, 1, 867-884.

Oliveira, M. M. d., Augusto, P. E. D., Cruz, A. G. d., \& Cristianini, M. (2014). Effect of dynamic high pressure on milk fermentation kinetics and rheological properties of probiotic fermented milk. Innovative Food Science E' Emerging Technologies, 26, 67-75.

Ong, L., \& Shah, N. P. (2009). Probiotic Cheddar cheese: Influence of ripening temperatures on survival of probiotic microorganisms, cheese composition and organic acid profiles. LWT - Food Science and Technology, 42(7), 1260-1268.

Ong, L., Henriksson, A., \& Shah, N. P. (2006). Development of probiotic Cheddar cheese containing Lactobacillus acidophilus, Lb. casei, Lb. paracasei and Bifidobacterium spp. and the influence of these bacteria on proteolytic patterns and production of organic acid. International Dairy Journal, 16(5), 446-456.

Ooi, L. -G., \& Liong, M. -T. (2010). Cholesterol-lowering effects of probiotics and prebiotics: A review of in vivo and in vitro findings. International Journal of Molecular Sciences, 11, 2499-2522.

Otoni, C. G., Avena-Bustillos, R. J., Olsen, C. W., Bilbao-Sáinz, C., \& McHugh, T. H. (2016a). Mechanical and water barrier properties of isolated soy protein composite edible films as affected by carvacrol and cinnamaldehyde micro and nanoemulsions. Food Hydrocolloids, 57, 72-79.

Otoni, C. G., Espitia, P. J. P., Avena-Bustillos, R. J., \& McHugh, T. H. (2016b). Trends in antimicrobial food packaging systems: Emitting sachets and absorbent pads. Food Research International, 83, 60-73.

Parvez, S., Malik, K. A., Ah Kang, S., \& Kim, H. Y. (2006). Probiotics and their fermented food products are beneficial for health. Journal of Applied Microbiology, 100, 1171-1185.

Paseephol, T., \& Sherkat, F. (2009). Probiotic stability of yoghurts containing Jerusalem artichoke inulins during refrigerated storage. Journal of Functional Foods, 1(3), 311-318.

Pereira, E. P. R., Cavalcanti, R. N., Esmerino, E. A., Silva, R., Guerreiro, L. R. M., Cunha, R. L., .. Cruz, A. G. (2016a). Effect of incorporation of antioxidants on the chemical, rheological, and sensory properties of probiotic petit suisse cheese. Journal of Dairy Science, 99(3), 1762-1772.

Pereira, E. P. R., Faria, J. A. F., Cavalcanti, R. N., Garcia, R. K. A., Silva, R., Esmerino, E. A., ... Cruz, A. G. (2016b). Oxidative stress in probiotic Petit Suisse: Is the jabuticaba skin extract a potential option? Food Research International, 81, 149-156.

Phillips, M., Kailasapathy, K., \& Tran, L. (2006). Viability of commercial probiotic cultures (L. acidophilus, Bifidobacterium sp., L. casei, L. paracasei and L. rhamnosus) in cheddar cheese. International Journal of Food Microbiology, 108(2), 276-280.

Piermaria, J., Diosma, G., Aquino, C., Garrote, G., \& Abraham, A. (2015). Edible kefiran films as vehicle for probiotic microorganisms. Innovative Food Science E Emerging Technologies, 32, 193-199.

Ranadheera, R. D. C. S., Baines, S. K., \& Adams, M. C. (2010). Importance of food in probiotic efficacy. Food Research International, 43(1), 1-7.

Ranadheera, C. S., Evans, C. A., Adams, M. C., \& Baines, S. K. (2012a). Probiotic viability and physico-chemical and sensory properties of plain and stirred fruit yogurts made from goat's milk. Food Chemistry, 135(3), 1411-1418.

Ranadheera, C. S., Evans, C. A., Adams, M. C., \& Baines, S. K. (2012b). In vitro analysis of gastrointestinal tolerance and intestinal cell adhesion of probiotics in goat's milk ice cream and yogurt. Food Research International, 49(2), 619-625.

Ranadheera, C. S., Evans, C. A., Adams, M. C., \& Baines, S. K. (2015). Microencapsulation of Lactobacillus acidophilus LA-5, Bifidobacterium animalis subsp. lactis BB-12 and Propionibacterium jensenii 702 by spray drying in goat's milk. Small Ruminant Research, 123(1), 155-159.

Ranadheera, C. S., Evans, C. A., Adams, M., \& Baines, S. K. (2016a). Co-culturing of probiotics influences the microbial and physico-chemical properties but not sensory quality of fermented dairy drink made from goats' milk. Small Ruminant Research, 136, 104-108.

Ranadheera, C. S., Evans, C. A., Adams, M., \& Baines, S. K. (2016b). Co-culturing of probiotics influences the microbial and physico-chemical properties but not sensory quality of fermented dairy drink made from goats milk. Small Ruminant Research, 136 104-108.

Rastall, R. A., Fuller, R., Gaskins, H. R., \& Gibson, G. R. (2000). Colonic functional foods. In G. R. Gibson, \& C. M. Williams (Eds.), Functional Foods. Cambridge: Woodhead Publishing Limited.

Romano, N., Tavera-Quiroz, M. J., Bertola, N., Mobili, P., Pinotti, A., \& Gómez-Zavaglia, A. (2014). Edible methylcellulose-based films containing fructo-oligosaccharides as vehicles for lactic acid bacteria. Food Research International, 64, 560-566.

Salminen, S., Ouwehand, A., Benno, Y., \& Lee, Y. K. (1999). Probiotics: How should they be defined? Trends in Food Science \& Technology, 10, 107-110.

Sánchez-González, L., Quintero Saavedra, J. I., \& Chiralt, A. (2013). Physical properties and antilisterial activity of bioactive edible films containing Lactobacillus plantarum. Food Hydrocolloids, 33, 92-98.

Sánchez-González, L., Quintero Saavedra, J. I., \& Chiralt, A. (2014). Antilisterial and physical properties of biopolymer films containing lactic acid bacteria. Food Control, 35, 200-206.

Santivarangkna, C., Naumann, D., Kulozik, U., \& Foerst, P. (2010). Protective effects of sorbitol during the vacuum drying of Lactobacillus helveticus: An FT-IR study. Annals of Microbiology, 60, 235-242.

Satish Kumar, R., \& Arul, V. (2015). Health benefits of human probiont Lactobacillus plantarum. Nutraceuticals and Functional Foods in Human Health and Disease Prevention (pp. 629-642). CRC Press.

Schirmer, B. C., Heiberg, R., Eie, T., Møretrø, T., Maugesten, T., Carlehøg, M., \& Langsrud, S. (2009). A novel packaging method with a dissolving $\mathrm{CO}_{2}$ headspace combined with organic acids prolongs the shelf life of fresh salmon. International Journal of Food Microbiology, 133, 154-160.

Shah, N. P. (2007). Functional cultures and health benefits. International Dairy Journal, 17, 1262-1277.

Singh, K., Kallali, B., Kumar, A., \& Thaker, V. (2011). Probiotics: A review. Asian Pacific Journal of Tropical Biomedicine, 1, S287-S290.

Soares, N. F. F., Pires, A. C. S., Camilloto, G. P., Santiago-Silva, P., Espitia, P. J. P., \& Silva, W. A. (2009). Recent patents on active packaging for food application. Recent Patents on Food, Nutrition \&' Agriculture, 1, 171-178.

Sohail, A., Turner, M. S., Coombes, A., Bostrom, T., \& Bhandari, B. (2011). Survivability of probiotics encapsulated in alginate gel microbeads using a novel impinging aerosols method. International Journal of Food Microbiology, 145, 162-168.

Soukoulis, C., Behboudi-Jobbehdar, S., Yonekura, L., Parmenter, C., \& Fisk, I. D. (2014a). Stability of Lactobacillus rhamnosus GG in prebiotic edible films. Food Chemistry, 159, 302-308.

Soukoulis, C., Yonekura, L., Gan, H. -H., Behboudi-Jobbehdar, S., Parmenter, C., \& Fisk, I (2014b). Probiotic edible films as a new strategy for developing functional bakery products: The case of pan bread. Food Hydrocolloids, 39, 231-242.

Soukoulis, C., Singh, P., Macnaughtan, W., Parmenter, C., \& Fisk, I. D. (2016). Compositiona and physicochemical factors governing the viability of Lactobacillus rhamnosus GG embedded in starch-protein based edible films. Food Hydrocolloids, 52, 876-887.

Tang, Y., Xie, F., Zhang, D., Zhu, M., Liu, L., Liu, P., \& Gu, C. (2015). Physical properties and prebiotic activity of maize starch-based functional films. Starch - Stärke, 67, 124-131.

Tapia, M. S., Rojas-Graü, M. A., Rodríguez, F. J., Ramírez, J., Carmona, A., \& Martin-Belloso, O. (2007). Alginate and gellan-based edible films for probiotic coatings on fresh-cut fruits. Journal of Food Science, 72, E190-E196.

Tripathi, P., \& Dubey, N. K. (2004). Exploitation of natural products as an alternative strategy to control postharvest fungal rotting of fruit and vegetables. Postharvest Biology and Technology, 32, 235-245.

U.S. Food and Drug Administration (2016). Guidance \& Regulation. Retrieved from http:/ www.fda.gov/Food/GuidanceRegulation/default.htm

van Loveren, H., Sanz, Y., \& Salminen, S. (2012). Health claims in Europe: Probiotics and prebiotics as case examples. Annual Review of Food Science and Technology, 3, 247-261.

Venugopalan, V., Shriner, K. A., \& Wong-Beringer, A. (2010). Regulatory oversight and safety of probiotic use. Emerging Infectious Diseases, 16(11), 1661-1665.

Vieira da Silva, B., Barreira, J. C. M., \& Oliveira, M. B. P. P. (2016). Natural phytochemicals and probiotics as bioactive ingredients for functional foods: Extraction, biochemistry and protected-delivery technologies. Trends in Food Science \& Technology, 50 144-158.

Vinderola, G., Binetti, A., Burns, P., \& Reinheimer, J. (2011). Cell viability and functionality of probiotic bacteria in dairy products. Frontiers in Microbiology, 2, 1-6.

Vonasek, E., Le, P., \& Nitin, N. (2014). Encapsulation of bacteriophages in whey protein films for extended storage and release. Food Hydrocolloids, 37, 7-13.

Wassenaar, T. M., \& Klein, G. (2008). Safety aspects and implications of regulation of probiotic bacteria in food and food supplements. Journal of Food Protection, 71 1734-1741. 